\title{
Insights on bio-degumming of kenaf bast based on metagenomic and proteomics
}

\author{
Sheng Wen Duan, Li Feng Cheng, Xiang Yuan Feng, Qi Yang, Zhi Yuan Liu, Ke Zheng and Yuan De Peng
}

\begin{abstract}
Background: Microbes play important roles in kanef-degumming. This study aims at identifying the key candidate microbes and proteins responsible for the degumming of kenaf bast (Hibiscus cannabinus). Kenaf bast was cut into pieces and immersed into microbia fermentation liquid collected from different sites. Fermentation liquid samples were collected at 0,40,110 and $150 \mathrm{~h}$ and then subjected to the 16S/18S rRNA sequencing analysis and isobaric tag for relative and absolute quantitation (iTRAQ) analysis. The microbial (bacterial and fungal) diversity and the differentially expressed proteins/peptides (DEPs) were identified.

Results: With the prolonged degumming time, the weight loss rate increased, the bacterial diversity was decreased. [Weeksellaceae], Enterobacteriaceae and Moraxellaceae were rapidly increased at $0 \sim 40 \mathrm{~h}$, and then decreased and were gradually replaced by Bacteroidaceae from $40 \mathrm{~h}$ to $150 \mathrm{~h}$. Similarly, Chryseobacterium and Dysgonomonas were gradually increased at $0 \sim 110 \mathrm{~h}$ and then decreased; Acinetobacter and Lactococcus were increased at $0 \sim 40 \mathrm{~h}$, followed by decrease. Bacteroides was the dominant genus at $150 \mathrm{~h}$. Sequencing $18 \mathrm{~S}$ rRNA-seq showed the gradually decreased Wallemia hederae and increased Codosiga hollandica during degumming. iTRAQ data analysis showed Rds1, and pyruvate kinase I was decreased and increased in the kanef-degumming, respectively. Other DEPs of ferredoxin I, superoxide dismutase and aconitatehydratase were identified to be related to the Glyoxylate and dicarboxylate metabolism (ko00630).

Conclusions: Bacteria including Chryseobacterium, Dysgonomonas, Acinetobacter, Lactococcus and Bacteroidesand fungi like Wallemia hederae and Codosiga hollandica are key candidate microbes for kanef degumming.
\end{abstract}

Keywords: Bio-degumming, Hibiscus cannabinus, Microbial diversity, iTRAQ

\section{Background}

Kenaf (Hibiscus cannabinus),which contains 8-16\% lignin, 53-66\% cellulose, $23-35 \%$ pectin and some hemicellulose, is an annual herbaceous bast fiber crop of the genus Malvaceae [1-3]. It is widely planted around the world, especially in the tropical and subtropical regions, such as Asia and Latin America. Kenaf fiber is widely used as an important basic raw material in textile, manufacturing and composite fabrication due to its strong pulling force $[1,4]$. However, the retting methods can influence the quality of kenaf fiber.

Retting based on the intervention of bacteria and microbia enzymes promotes the development of the textile industry via resulting in a better quality of fibers. Conventional methods for the degumming of kenaf bast included traditional natural fermentation (water retting) and chemical degumming. In comparison with the

\footnotetext{
* Correspondence: hunandsw@163.com

Institute of Bast Fiber Crops, Chinese Academy of Agriculture Sciences, Changsha 410000, China
}

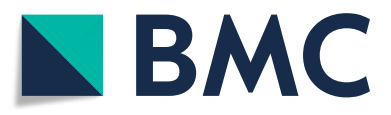

(c) The Author(s). 2020 Open Access This article is distributed under the terms of the Creative Commons Attribution 4.0 International License (http://creativecommons.org/licenses/by/4.0/), which permits unrestricted use, distribution, and

reproduction in any medium, provided you give appropriate credit to the original author(s) and the source, provide a link to the Creative Commons license, and indicate if changes were made. The Creative Commons Public Domain Dedication waiver (http://creativecommons.org/publicdomain/zero/1.0/) applies to the data made available in this article, unless otherwise stated.

natural fermentation and chemical degumming, biological (bacterial and enzymatic) degumming presents a series of advantages including high efficiency, low pollution, low cost and high fiber quality [3,5-7]. The secretion of bacteria promote the decomposition of material, which can be used for bacteria to continue to grow [6, 8]. Ideal bacterial strains for kenaf degumming should have the advantages of secreting pectinase, hemicellulose, and ligninase, but not cellulase [6-8].

The screening of superior bacterial strains with the activity of pectate lyase, pectinase, hemicellulase and/or ligninase and the preservation of the natural fiber structure and mechanical properties is crucial for biological degumming [7-9]. A series of bacterial strains have been identified with strong ability of retting or degumming, like Bacillus cereus hn1-1 [10], B. pumilus [7], B. licheniformis and B. subtilis [11] and B. tequilensis SV11-UV37 [6]. Cheng et al. [10] showed that the $10 \mathrm{~h}$-degumming process by $B$. cereus hn $1-1$ produced a residual gum rate as low as $5 \%$ and the 
fiber rate as high as $76 \%$. Mao et al. [12] reported that the ramie retting could be completed within $56 \mathrm{~h}$ by using a microbia consortium RAMCD407 plus $0.2 \% \mathrm{NaOH}$, with $2.84 \%$ residual gum content and $5.2 \mathrm{cN} / \mathrm{dtex}$ breaking strength of the final fiber. In addition, our previous study [7] identified that pectinase and mannanase were the key enzymes in the degumming of kenaf bast mediated by bacteria including B. pumilus, B. alcalophilus, Clostridium tertium, Brevibacillus brevis, Pectobacterium carotovora, Erwinia chrysanthemi, and Tyromyces subcaesius. All these results suggested the pivotal roles of bacteria in the degumming of kenaf bast. However, there was no systematic analysis for the alterations of bacterial secretome during degumming of kenaf bast.

This study was performed to identify the key candidate microbes and secretory proteins during the retting and degumming of kenaf bast. Alterations of microbial proteomics and community during retting and degumming of kenaf bast was detected using isobaric tags for relative and absolute quantitation (iTRAQ) and 16S/18S rRNA sequencing, respectively. These findings provide novel insights into the retting and degumming of kenaf bast.

\section{Results}

\section{Degumming of kenaf bast and bacteria collection}

The weight loss rate of kenaf bast was gradually increased with degumming, ranging from $11.72 \%$ at $40 \mathrm{~h}$ and $32.06 \%$ at $190 \mathrm{~h}$ (Table 1). The bacterial viable count, however, was primarily decreased from initial $4.2 \times 10^{7} \mathrm{CFU} / \mathrm{ml}$ to $8.7 \times 10^{6} \mathrm{CFU} / \mathrm{ml}$ at $40 \mathrm{~h}$ post fermentation. It was increased to the maximum $5.1 \times 10^{8}$ $\mathrm{CFU} / \mathrm{ml}$ at $150 \mathrm{~h}$, followed with a decrease. These results might suggest that the growth of bacteria had degumming function.

\section{General characteristics of $16 \mathrm{~S} / 18 \mathrm{~S}$ rRNA sequencing}

We then collected liquid samples at $0,40,110$ and $150 \mathrm{~h}$ post retting and subjected to $16 \mathrm{~S} / 18 \mathrm{~S}$ rRNA sequencing. A total of 167,321 and 181,887 raw reads was generated from $16 \mathrm{~S}$ and $18 \mathrm{~S}$ rRNA sequencing data, respectively. After removing the low-quality reads and chimera, the sequence length of trimmed reads is mostly distributed at $420 \mathrm{bp}-490 \mathrm{bp}$ in bacteria, and the fungus sample is mostly distributed at $399 \mathrm{bp}-409 \mathrm{bp}$. The final rank abundance curve tends to a plateau, indicating that the sample species are richer in composition and higher in uniformity (Fig. 1). The higher species rank value of samples at $0 \mathrm{~h}(500-600)$ compared with of samples at
40,110 and $140 \mathrm{~h} \mathrm{(200-300)}$ indicated that the fermentation significantly decreased bacterial diversity. In addition, we found the retting significantly reduced the bacterial alpha diversity estimators like Chao 1, PD whole_tree, Shannon and Simpson index (Table 2). In addition, retting also decreased fungal alpha diversity estimators including Chao 1 and PD_whole_tree, but increased Goods coverage (Table 2). These changes suggested retting decreased microbes viable count and bacterial diversity but increased fungal diversity.

\section{Identification of key bacteria responsible for the degumming of kenaf bast}

After OTUs (operational taxonomic units) annotation, we identified the abundances (at phylum level) of Bacteroidetes (from $34.91 \%$ at $0 \mathrm{~h}$ to $67.75 \%$ at $150 \mathrm{~h}$ ) and Patescibacteria (1.00 to $9.53 \%$ ) were gradually increased during the degumming of kenaf bast (Additional file 1: Figure S1), which replaced the Proteobacteria. The initial abundance of Firmicutes $(2.83 \%)$ was firstly increased to $15.28 \%$ at $40 \mathrm{~h}$ and then decreased to $3.40 \%$ at $150 \mathrm{~h}$ (Additional file 1: Figure S1a and b). At the family level, Sphingobacteriaceae (10.98\%, Bacteroidetes), Flavobacteriaceae (9.62\%), Burkholderiaceae (8.13\%), and Sphingomonadaceae (6.77\%) were the dominant bacteria at the initial (Fig. 2a and b). However, they were replaced by the fast-growing [Weeksellaceae] (21.55\%, Bacteroidetes), Enterobacteriaceae (16.41\%, Proteobacteria) and Moraxellaceae (12.13\%, Proteobacteria) families at $40 \mathrm{~h}$ post retting. The latter bacteria were gradually replaced by the Bacteroidaceae family from $40 \mathrm{~h}$ to $150 \mathrm{~h}$ (25.89\%; Fig. 2a and b). We also identified that the growth of Cytophagaceae and Chitinophagaceae families (Bacteroidetes) were inhibited by retting process. Similar changes were found in several bacterial genera. Dominant genera, including Pedobacter (9.10\%), Flavobacterium (6.86\%), Pseudomonas (5.97\%) and Brevundimonas (5.64\%) kept an equivalent level at the initial $(0 \mathrm{~h})$. Chryseobacterium (15.03\%, [Weeksellaceae]), Acinetobacter (12.10\%, Moraxellaceae) and Lactococcus (8.84\%, Streptococcaceae family) grew to be the dominant bacteria at $40 \mathrm{~h}$, which were then replaced by Bacteroides (25.89\%) in the fermentation liquid, followed by Chryseobacterium (16.03\%) and Dysgonomonas families (15.96\%) (Fig. 2c and d). These changes in bacterial abundances were in response to that of the bacterial viable count in Table 1. These data showed that Acinetobacter, Chryseobacterium, Lactococcus and Bacteroidetes at genus level and [Weeksellaceae], Enterobacteriaceae, Moraxellaceae and Bacteroidaceae at family level

Table 1 Kenaf bast degumming effect during different enrichment time

\begin{tabular}{llllll}
\hline Terms & $0 \mathrm{~h}$ & $40 \mathrm{~h}$ & $110 \mathrm{~h}$ & $150 \mathrm{~h}$ & $190 \mathrm{~h}$ \\
\hline Weight loss rate (\%) & - & 11.72 & 24.45 & 31.26 & 32.06 \\
Initial content of live bacterial (CFU/mL) & $4.2 \times 10^{7}$ & $8.7 \times 10^{6}$ & $7.2 \times 10^{7}$ & $5.1 \times 10^{8}$ & $3.1 \times 10^{8}$ \\
\hline
\end{tabular}



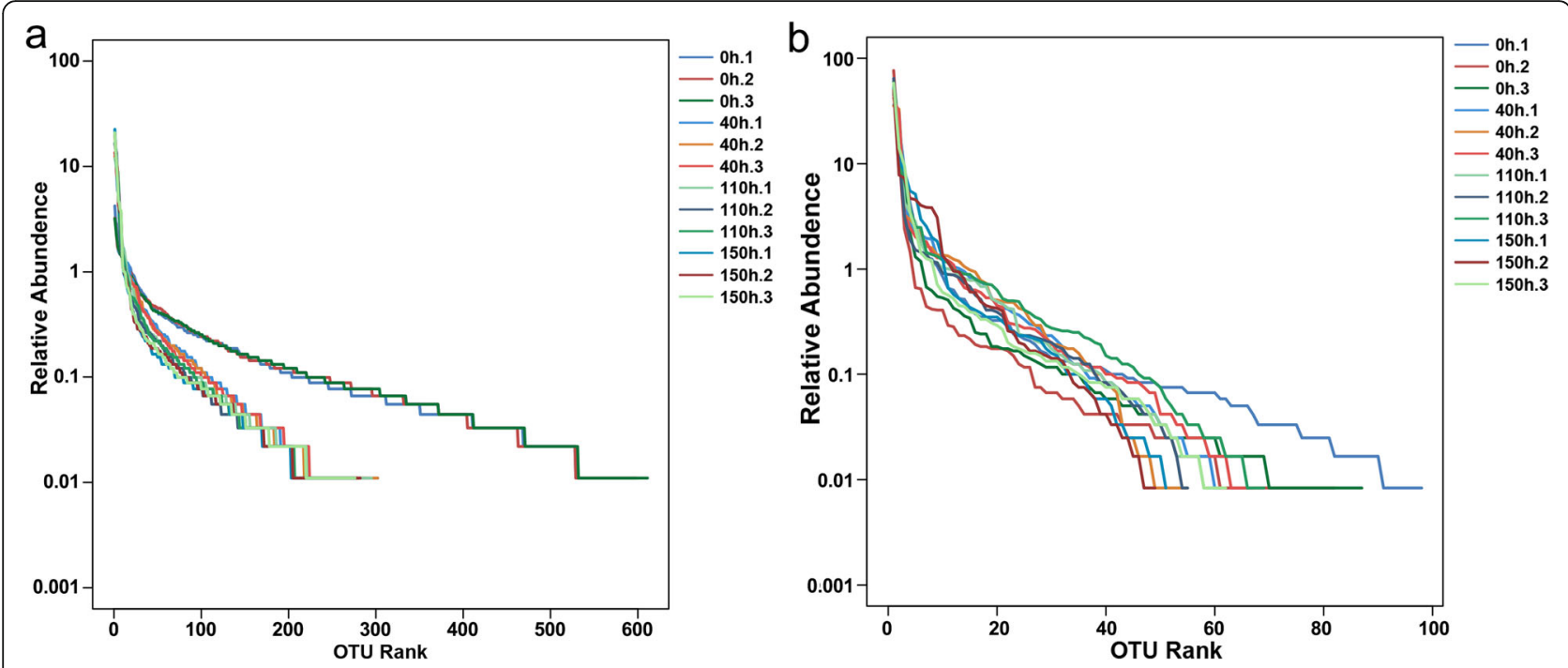

Fig. 1 Rank Abundance curves of 12 samples. The different color represent different samples. a . Rank Abundance curves of bacteria; $\mathbf{b}$. Rank Abundance curves of fungi

might be key candidate bacteria responsible for the degumming of kenaf bast.

\section{Identification of key fungi responsible for the degumming of kenaf bast}

As expected, fungal abundances were also changed in response to degumming. All fungi were mainly dominanted by 2 phyla: Opisthokonta (98.73\%) and SAR (1.24\%). The relative abundance of Opisthokonta subkingdom was gradually decreased to $85.09 \%$, and replaced by $S A R$ phylum (14.61\% at $150 \mathrm{~h}$; Fig. 3a). The dominant fungal families Incertae Sedis (61.11 to $8.10 \%)$ and Pezizomycotina (18.73 to $3.89 \%$ ) were replaced by Dipodascaceae (5.98 to $53.08 \%$ ) and some other fungi such as Bulleribasidiaceae, Craspedida, Chrysophyceae, etc. (Fig. 3b). At genus level, the results showed that Wallemia (60.43\%) and Eurotiomycetes (18.55\%) were the dominant fungi (Fig. 3c). As for specific species, the dominant positions of Wallemia hederae $(60.33 \%)$ at the initial, but decreased at $40 \mathrm{~h}$ (36.97\%), $110 \mathrm{~h}(12.12 \%)$ and $150 \mathrm{~h}$ (7.50\%) (Fig. 3d). The relative abundance of Codosiga hollandica species was increased from $0.16 \%$ at $0 \mathrm{~h}$ to $2.42 \%$ at $150 \mathrm{~h}$.

\section{Microbia secretomics analysis and identification of candidate proteins or peptides}

We then performed the secretomics analysis to identify the candidate proteins which might be responsible for biological degumming of kenaf bast, since there are significant changes in the relative abundance of bacteria and fungi. A total of 197 proteins, including 67 DEPs were identified (Additional file 2: Table S1). Clustering analysis showed the distinct expression patterns of these proteins in the samples (Fig. 4). We identified the significantly down regulated Rds1 protein peptides (including

Table 2 The alpha diversity of the $16 \mathrm{~S}$ and $18 \mathrm{~S}$ rRNA-seq

\begin{tabular}{|c|c|c|c|c|c|}
\hline \multirow[t]{2}{*}{ Group } & \multicolumn{5}{|l|}{$16 \mathrm{~S}$ rRNA-seq } \\
\hline & Chao 1 & Goods coverage & PD_whole_tree & Shannon & Simpson \\
\hline $\mathrm{Oh}$ & $642.47 \pm 8.45^{a}$ & $0.9920 \pm 0.0002^{a}$ & $25.62 \pm 0.21^{a}$ & $8.01 \pm 0.05^{a}$ & $0.9924 \pm 0.0006^{a}$ \\
\hline $40 h$ & $388.16 \pm 13.70^{b}$ & $0.9912 \pm 0.0003^{b}$ & $12.83 \pm 0.14^{b}$ & $5.53 \pm 0.06^{b}$ & $0.9447 \pm 0.0015^{b}$ \\
\hline $110 \mathrm{~h}$ & $341.90 \pm 12.46^{c}$ & $0.9923 \pm 0.0003^{a}$ & $11.52 \pm 0.43^{c}$ & $5.09 \pm 0.17^{c}$ & $0.9275 \pm 0.0102^{c}$ \\
\hline \multirow[t]{2}{*}{$150 \mathrm{~h}$} & $353.47 \pm 5.32^{c}$ & $0.9919 \pm 0.0003^{a}$ & $12.25 \pm 0.19^{b}$ & $4.75 \pm 0.06^{d}$ & $0.9058 \pm 0.0043^{d}$ \\
\hline & 18S rRNA-seq & & & & \\
\hline $\mathrm{Oh}$ & $98.86 \pm 4.15^{a}$ & $0.9988 \pm 0.0004^{b}$ & $3.09 \pm 0.30^{a}$ & $2.26 \pm 0.59^{b}$ & $0.58 \pm 0.14^{b}$ \\
\hline $40 h$ & $62.75 \pm 3.77^{b}$ & $0.9996 \pm 0.0001^{a}$ & $2.27 \pm 0.32^{b c}$ & $3.01 \pm 0.07^{a}$ & $0.75 \pm 0.01^{a}$ \\
\hline $110 \mathrm{~h}$ & $65.79 \pm 3.94^{b}$ & $0.9996 \pm 0.0000^{a}$ & $2.45 \pm 0.23^{b}$ & $2.75 \pm 0.30^{a b}$ & $0.64 \pm 0.05^{a b}$ \\
\hline $150 \mathrm{~h}$ & $56.10 \pm 8.06^{b}$ & $0.9997 \pm 0.0002^{a}$ & $1.92 \pm 0.07^{c d}$ & $2.78 \pm 0.24^{a b}$ & $0.69 \pm 0.04^{a b}$ \\
\hline
\end{tabular}




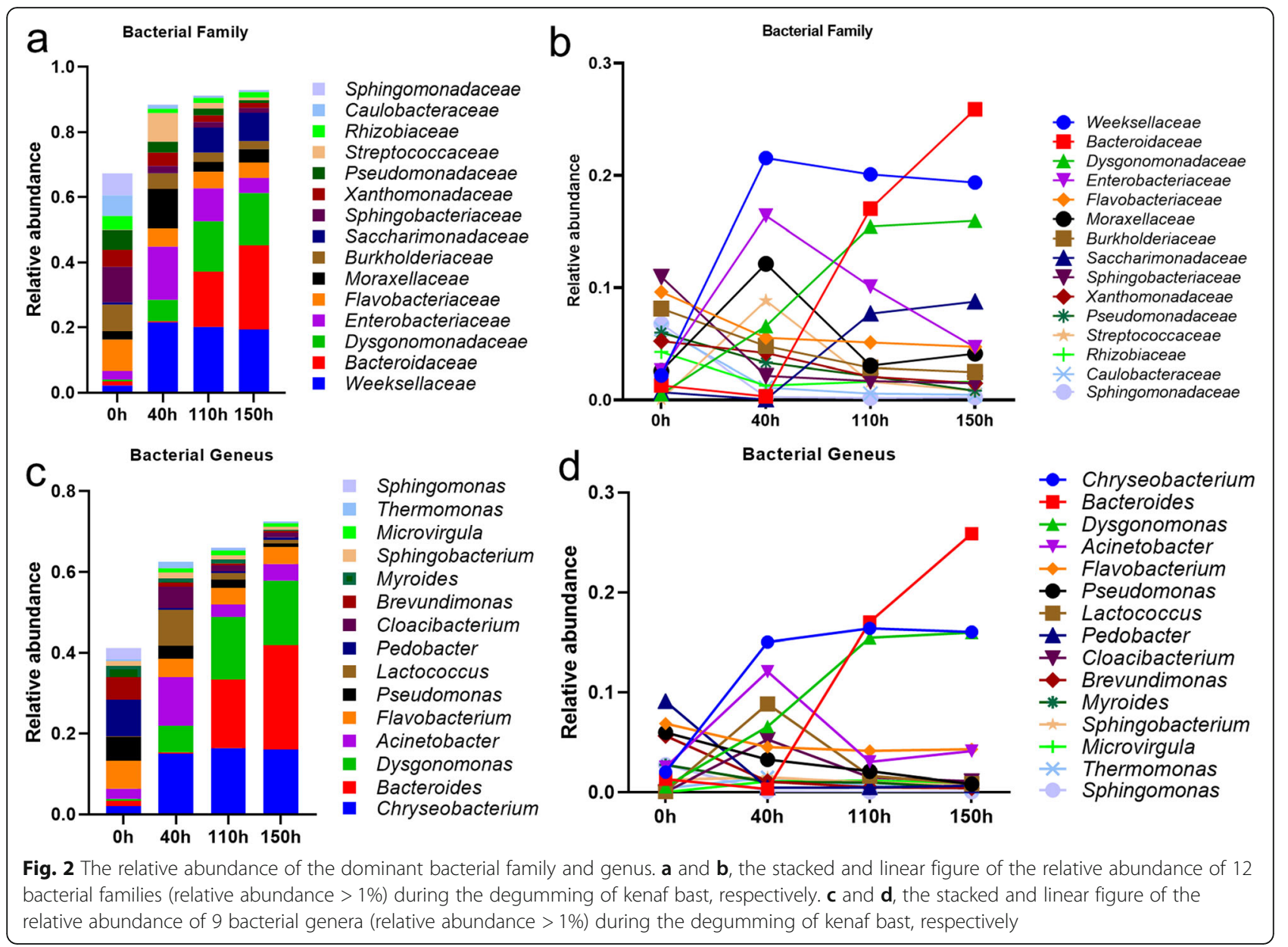

I4YCX5 and R9AEW5, A1DDU4, A0A0S7E3J2, A0A0J5 SQP1, Q4WVL1, B0Y1F6, A0A084BN00 and A0A0K8L4 F0), superoxide dismutase peptides (J1ACL6 and A0A0Q 9DZS2), and the upregulated peptides of pyruvate kinase I (A0A0A2W3C3), lipoprotein (A0A0N7K9K4), ferredoxin I (I4JHJ), thioredoxin (A0A088F1E4, A0A0M2 Y158 and A0A0M3C9P8). A0A0A2W3C3 was enriched into the pathways including glucagon signaling pathway (ko04922) and pyruvate metabolism (ko0492). A peptide of aconitatehydratase (aconitase, ACO), which is related to the glyoxylate and dicarboxylate metabolism (ko0063 0 ), was decreased at $40 \mathrm{~h}$ and then increased at 110 and $150 \mathrm{~h}$ post retting compared with $0 \mathrm{~h}$ (Table 3 ). Most of the other peptides were annotated with transporter activities (Additional file 2: Table S1).

Among the other non-DEPs, we identified that the peptide of Aldehyde dehydrogenase family protein (A0A160 F3I4), Aspartate aminotransferase (A0A0A2VU16) and 6phosphogluconate dehydrogenase (L8X2A2). The L8X2A2 was identified to be related with pentose phosphate pathway.

\section{Discussion}

The degumming of kenaf bast is a process mediated by dynamic change of microbes. Using the $16 \mathrm{~S} / 18 \mathrm{~S}$ rRNA sequencing, we identified the changed bacterial and fungal abundance during the degumming of kenaf bast (0 150 h). In the fermentation liquid, the growth of Cytophagaceae and Chitinophagaceae was inhibited during the degumming of kenaf bast. Many bacteria genera played crucial roles in in the degumming process of kenaf bast, such as Bacteroides, Chryseobacterium, Dysgonomonas, Acinetobacter, and Lactococcus, of which the abundance were greatly changed with degumming treatment. Similarly, some fungi also participated in the degumming process of kenaf bast including Pezizomycotina, Dipodascaceae, Codosiga hollandica, and Incertae Sedis. The abundance of subdivided Wallemia and Eurotiomycetes genera were dramatically reduced in the process of dealkylation and fermentation. And the increased Dipodascaceae family might promote the degumming of kenaf bast. A series of Bacillus strains has been identified to be ramie- or kanefdegumming strains, like B. cereus hn1-1 [10], B. pumilus 

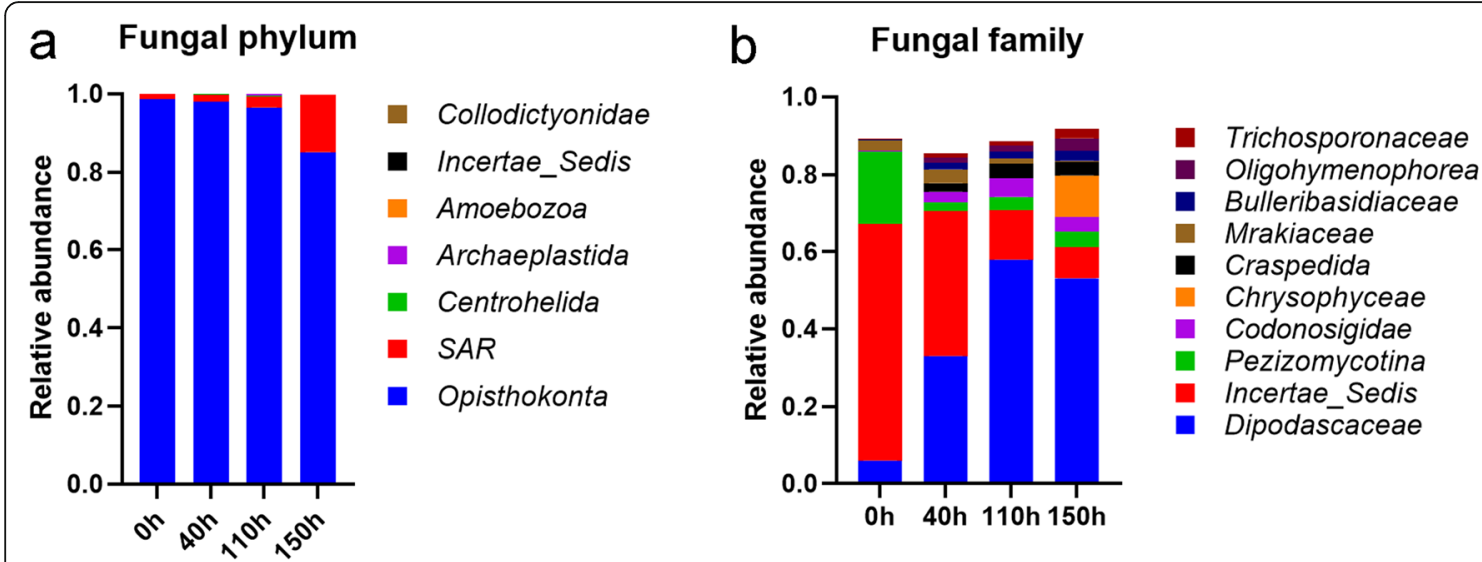

C Fungal genus
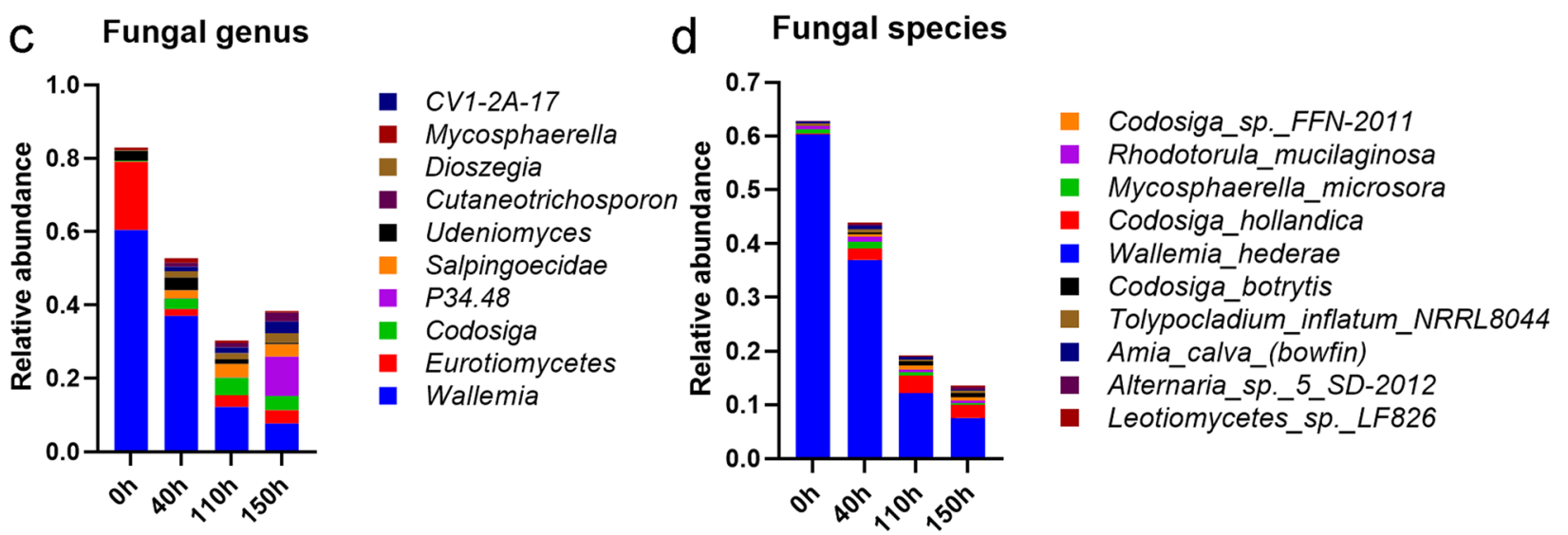

Fig. 3 The relative abundance of the dominant fungal family. a to $\mathbf{d}$, the stacked figure of the relative abundance of dominate fungal at phylum, family, genus and species level during the degumming of kenaf bast, respectively

[7], B. licheniformis and B. subtilis [11] and B. tequilensis SV11-UV37 [6]. In addition, our previous study [7] showed that seven bacterial strains belonging to the species including B. pumilus, B. alcalophilus, C. tertium, Brevibacillus brevis, Pectobacterium carotovora, Erwinia chrysanthemi and Tyromyces sub caesius were the key in strains for the degumming of kenaf bast. Other reports also showed the ability of B. licheniformis, Paenibacillus macerans, C. tertium, B. tequilensis and B. vulgatusor the proteases and pectinolytic enzymes derived from these strains for degumming fiber, wool and wood $[6,7,13,14]$. For instance, enzymatic treatment is an acceptable method of intervention among the methods for wool treatment for breaking down the surface structure [14]. Serine proteases are the most common commercial proteases derived from Bacillus strains.

For the degumming of plant fibers, some researchers had isolated proteases, xylanases and pectate lyases from the bacteria like Acinetobacter spp. (>1 species of the genus) [15] and B. cereus [16] and fungi including Extremophilic fungi [17-19]. Researchers also identified the lignin degrading role of Pseudomonas, Lactococcus and Acinetobacter strains in hemp, ramie and mechanical pulp
[20-23]. For instance, Hu et al. [23] observed that abundances of Pseudomonas and Acinetobacter were increased to the highest at $36 \mathrm{~h}$ post retting and decreased subsequently. In particular, the finding about Acinetobacter and Lactococcus was consistent with our results, which was increased to 12.09 and $8.84 \%$ at $40 \mathrm{~h}$ and then decreased to 4.10 and $0.84 \%$ at $150 \mathrm{~h}$. The dynamic changes of these bacteria during the degumming of kanef bast suggested their crucial roles in degrading kanef.

Kanef-degumming is a dynamic process of bacterial adaptation and growth. The initial stage is characterized by decreased bacterial richness and diversity [24]. We determined the decreased bacterial viable count at the $40 \mathrm{~h}$ post retting, followed by increased bacterial viable count but not bacterial richness and diversity. Our present study presented a cluster of anaerobic Bacteroidaceae members like Bacteroides, Chryseobacterium and Dysgonomonas, played crucial roles in the degumming of kanef bast, especially in the late stage. Cytophagaceae was initially inhibited, which might guarantee the fiber structure. The rapid growth of anaerobic Bacteroidaceae bacteria changed bacterial diversity. Xylan and pentose (including xylose) are main components of hemicellulose in plants [25]. The degradation of hemicellulose into 


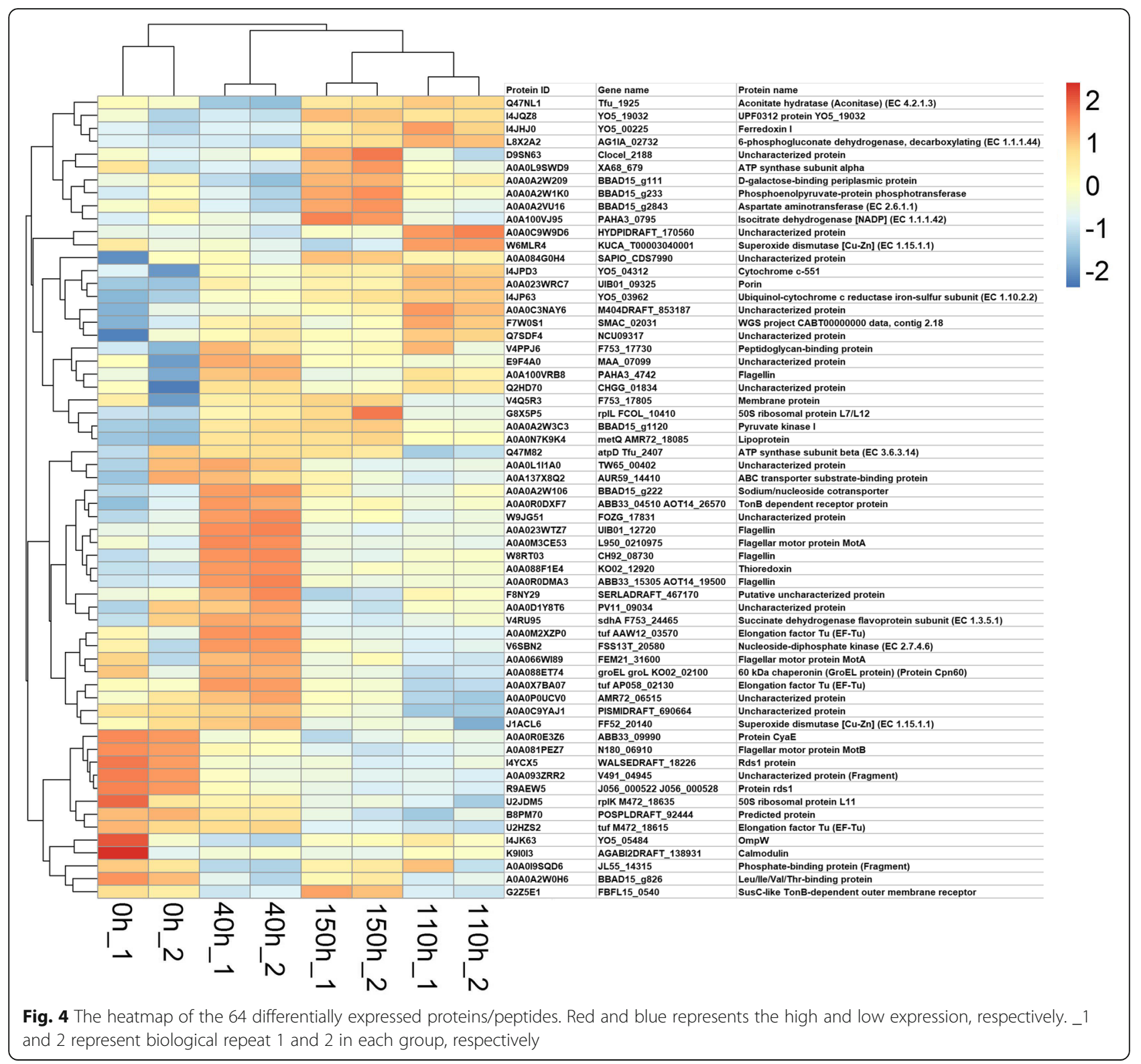

oligomers and sugarsis a metabolic property shared by sugar-fermenting Bacteroides [26-29]. The increased abundance of these Bacteroidaceae members might suggest the accumulation of their substrates derived from the early stage fermentation from aerobic bacteria like Acinetobacter and Lactococcus or the changed environments.

In addition, we also identified the down regulation of several peptides of Rds1 during the degumming of kanef bast. Rds1 a stress-responsible protein, which could be depressed by starving from glucose, ammonium, phosphate, exposuring to carbon dioxide and high temperature [30]. The down regulation of it was theoretically in line with the hypothesis that the starvation of sugar and oxygen of early retting stage. What's more, the identification of the gradually decreased halophilic Wallemia hederae and increased turfgrass pathogen in the fermentation liquid might suggest the deterioration of fermentation. Codosiga hollandica.

\section{Conclusions}

In conclusion, we identified a cluster of key bacteria responsible for the degumming of kanef bast. We identified that the growth of Cytophagaceae was initially inhibited at the early stage of degumming for kenaf bast. The up-anddown change in the abundance of Acinetobacter and Lactococcus (Streptococcaceae) and the gradually increased growth of Bacteroides, Chryseobacterium, Dysgonomonas characterized the degumming process. In addition, we also identified the increased Codosiga hollandica and decreased Wallemia hederae fungus family during degumming for $150 \mathrm{~h}$. Secretory proteomics analysis showed Rds1, pyruvate 
Table 3 Several differentially expressed proteins in during degumming

\begin{tabular}{|c|c|c|c|c|c|c|c|}
\hline \multirow[t]{2}{*}{ Protein ID } & \multirow[b]{2}{*}{$\mathrm{Oh}$} & \multicolumn{3}{|c|}{ Time (s) } & \multirow[t]{2}{*}{ Protein name } & \multirow[t]{2}{*}{ Gene ontology } & \multirow[t]{2}{*}{ Pathway } \\
\hline & & $40 \mathrm{~h}$ & $110 \mathrm{~h}$ & $150 \mathrm{~h}$ & & & \\
\hline $\begin{array}{l}\text { R9AEW5;A1DDU4; } \\
\text { A0A0S7E3J2; } \\
\text { A0AOJ5SQP1; } \\
\text { Q4WL1;BOY1F6; } \\
\text { A0A084BN00; } \\
\text { A0AOK8L4F0 }\end{array}$ & 4391.5 & 715.0 & 340.8 & 362.7 & Protein rds1 & & \\
\hline A0A0N7K9K4 & 889.5 & 2642.3 & 1897.0 & 2776.1 & Lipoprotein & & \\
\hline A0A023WRC7 & 308.7 & 614.1 & 981.2 & 671.3 & Porin & $\begin{array}{l}\text { integral component of membrane } \\
\text { [GO:0016021]; porin activity [GO:0015288] }\end{array}$ & \\
\hline $14 Y C X 5$ & $\begin{array}{l}15 \\
628.3\end{array}$ & 386.7 & 228.8 & 254.1 & Rds1 protein & & \\
\hline $\mathrm{A} 0 \mathrm{~A} 0 \mathrm{~A} 2 \mathrm{~W} 3 \mathrm{C} 3$ & 964.2 & 4595.7 & 2396.7 & 5424.1 & Pyruvate kinase I & & $\begin{array}{l}\text { ko04922: Glucagon } \\
\text { signaling pathway; } \\
\text { ko0492: Pyruvate } \\
\text { metabolism }\end{array}$ \\
\hline I4JHJO & 580.1 & 651.8 & 2090.5 & 1518.2 & Ferredoxin I & & \\
\hline Q47NL1 & 816.8 & 199.8 & 2134.1 & 1615.2 & $\begin{array}{l}\text { Aconitate hydratase } \\
\text { (Aconitase) (EC 4.2.1.3) }\end{array}$ & $\begin{array}{l}4 \text { iron, } 4 \text { sulfur cluster binding [GO:0051539]; } \\
\text { aconitate hydratase activity [GO:0003994]; } \\
\text { metabolic process [GO:0008152] }\end{array}$ & $\begin{array}{l}\text { ko00630: Glyoxylate } \\
\text { and dicarboxylate } \\
\text { metabolism }\end{array}$ \\
\hline $\begin{array}{l}\text { AOA088F1E4; } \\
\text { A0A0M2Y158; } \\
\text { A0A0M3C9P8 }\end{array}$ & 201.3 & 1957.3 & 429.8 & 1047.9 & Thioredoxin & $\begin{array}{l}\text { protein disulfide oxidoreductase activity } \\
\text { [GO:0015035]; cell redox homeostasis } \\
\text { [GO:0045454]; glycerol ether metabolic } \\
\text { process [GO:0006662] }\end{array}$ & \\
\hline $\begin{array}{l}\text { J1ACL6; } \\
\text { A0A0Q9DZS2 }\end{array}$ & 393.9 & 447.6 & 286.3 & 325.2 & $\begin{array}{l}\text { Superoxide dismutase } \\
\text { [Cu-Zn] (EC 1.15.1.1) }\end{array}$ & $\begin{array}{l}\text { metal ion binding [GO:0046872]; superoxide } \\
\text { dismutase activity [GO:0004784] }\end{array}$ & \\
\hline $\begin{array}{l}\text { W6MLR4;WOTF05; } \\
\text { A0A090C5A2 }\end{array}$ & 1289.9 & 1014.2 & 2316.6 & 770.7 & $\begin{array}{l}\text { Superoxide dismutase } \\
\text { [Cu-Zn] (EC 1.15.1.1) }\end{array}$ & $\begin{array}{l}\text { metal ion binding [GO:0046872]; superoxide } \\
\text { dismutase activity [GO:0004784] }\end{array}$ & \\
\hline $\begin{array}{l}\text { V4RU95;S6LCD6; } \\
\text { M2UZN0;LOGJW1; } \\
\text { I4JML0;14CTX4; } \\
\text { H7FOP7;F8H871; } \\
\text { F2MXE8;A4VKP6; } \\
\text { A0A137Y7T1; } \\
\text { A0A137WWW6; } \\
\text { A0A0I9SRB2; } \\
\text { A0A0H3YZE1; } \\
\text { A0A0D7EA74; } \\
\text { A0A0C2MWX1; } \\
\text { A0A098FQU9; } \\
\text { A0A061JVN2; } \\
\text { A0A023WTY8 }\end{array}$ & 1525.4 & 2439.2 & 1244.5 & 1037.6 & $\begin{array}{l}\text { Succinate } \\
\text { dehydrogenase } \\
\text { flavoprotein subunit } \\
\text { (EC 1.3.5.1) }\end{array}$ & $\begin{array}{l}\text { plasma membrane [GO:0005886]; flavin adenine } \\
\text { dinucleotide binding [GO:0050660]; succinate } \\
\text { dehydrogenase (ubiquinone) activity [GO:0008177]; } \\
\text { electron transport chain [GO:0022900]; tricarboxylic } \\
\text { acid cycle [GO:0006099] }\end{array}$ & \\
\hline A0A0D1Y8T6 & 1129.9 & 1915.8 & 958.2 & 658.1 & $\begin{array}{l}\text { Uncharacterized } \\
\text { protein }\end{array}$ & succinate dehydrogenase activity [GO:0000104] & \\
\hline H7FVF4 & 147.3 & 38.6 & 124.9 & 289.2 & $\begin{array}{l}\text { Isocitrate lyase } \\
\text { (EC 4.1.3.1) }\end{array}$ & $\begin{array}{l}\text { isocitrate lyase activity [GO:0004451]; carboxylic } \\
\text { acid metabolic process [GO:0019752] }\end{array}$ & \\
\hline
\end{tabular}

kinase I and aconitatehydratase peptides were changed during the degumming of kanef bast. These findings provide evidence on the crucial roles of these microbes in the degumming of kenaf bast.

\section{Methods}

\section{Bacteria collection and degumming of kenaf bast}

Humus samples (50 g) were collected from Sanya, China. Water samples $(100 \mathrm{ml})$ were collected from a conventional retting pond ( $50 \mathrm{~cm}$ away from the water surface) in
Xiaoshan, Zhejiang, China. Soil samples (50 g) were collected from continuous cropping soil of Kenaf in Xiaoshan. Soil and humus samples were diluted into 100 $\mathrm{ml}$ bacteria free water (autoclave at $121^{\circ} \mathrm{C}$ for $20 \mathrm{~min}$ ), filtered and then mixed with the above water samples.

Kenaf bast was collected from Xianghongma No. 1 plants in Changsha, China. The samples were cut into pieces $(3 \mathrm{~cm})$ and then immersed into bacteria mixture (10 g: $5 \mathrm{ml}$ ) with supplementation of $100 \mathrm{ml}$ bacteria free water. For the degumming of kenaf bast, samples were 
maintained on an orbital shaker at $30^{\circ} \mathrm{C}, \mathrm{pH} 7.0$, for 30 min. Then the fermentation liquid samples were collected at $0,40,110,150$ and $190 \mathrm{~h}$ post degumming and used for further analysis. Each experiment was done in triplicates.

\section{Determination of kenaf bast weight loss rate and viable count of bacteria}

The weight loss rate of the kenaf bast samples in each condition was calculated according to the following formula: weight loss rate $(\%)=$ [initial weight $(10 \mathrm{~g})$-final weight $(\mathrm{g})$ of kenaf bast]/initial weight $(10 \mathrm{~g})$ of kenaf bast $\times 100 \%$. Total viable count was quantified traditionally using the colony-forming units (CFUs) after incubation on nutrient broth solid media ( $\mathrm{pH} \mathrm{7.0)}$ for 0-190 h.

\section{DNA extraction and $16 \mathrm{~S}$ and $18 \mathrm{~S}$ ribosomal RNA gene sequencing}

DNA extraction was performed using a PowerSoil ${ }^{\mathrm{TM}}$ DNA Isolation Kit (MOBIO laboratories, San Diego, Carlsbad, California, USA). The concentration and purity of the DNA was measured by agarose gel electrophoresis. The $16 \mathrm{~S}$ ribosomal DNA (rDNA) gene V3-V4 region of the bacteria was amplified by PCR with bar coded primers (343F: $5^{\prime}$ - TAC GGRAGGCAGCAG - 3' and 798R: 5' - AGGGTATCTA ATCCT-3'), using FastPfu Polymerase (TransStart, Beijing, China). The PCR primers for the $18 \mathrm{~S} \mathrm{rDNA}$ of fungus were NS1: 5' - GTAGTCATATGCTTGTCTC - 3' and NS8: 5' TCCGCAGGTTCACCTACGGA - 3'. Reaction parameters were: $95^{\circ} \mathrm{C}$ for $5 \mathrm{~min}$, followed by 30 cycles of $95^{\circ} \mathrm{C} 30$ s, $52{ }^{\circ} \mathrm{C} 45 \mathrm{~s}(16 \mathrm{~S})$ or $1 \mathrm{~min}(18 \mathrm{~S}), 72^{\circ} \mathrm{C} 1 \mathrm{~min}$, and the final step of $72{ }^{\circ} \mathrm{C}$ for $10 \mathrm{~min}$. The amplicons of $16 \mathrm{~S}$ and $18 \mathrm{~S}$ rDNA were purified by an AxyPrep DNA Gel Extraction Kit (Axygen Biosciences, Union City, California, USA). After repeating the above steps (amplification and purification), the concentration of final purified amplicons was detected by Qubit 2.0 (Thermo Fisher Scientific, Walthan, Massachusetts, USA). At the end, the samples were pooled and subjected to an Illumina MiSeq Instrument (Illumina, San Diego, California, USA) in Shanghai OE Biotech. Co., Ltd. with $350 \mathrm{bp}$ paired-end sequencing.

\section{Data processing}

Raw data from different samples were identified based on the unique barcode. The primer sequences were removed and data were trimmed using U-Search software [31]. FLASH v1.2.7 software (http://ccb.jhu.edu/software/FLASH) was used for merging paired-end reads and the counting of reads [32]. The chimeric sequences were removed using UCHIME (http://www.drive5.com/ usearch/index.html) [33]. Sequences were clustered into OTUs by QIIME (v1.8.0, http://qiime.org/) [34] according to the minimal $97 \%$ similarity. Through matching to the Silva database (https://www.arb-silva.de/) [35], the taxonomic information for each OTU was obtained. Alpha and beta diversities were analyzed to determine differences among groups in terms of species complexity by QIIME (v1.8.0) software.

\section{Protein extraction, digestion, and ITRAQ labeling}

Fermentation liquid samples $(30 \mathrm{ml})$ were collected at $0 \mathrm{~h}$, $40 \mathrm{~h}, 110 \mathrm{~h}$ and $150 \mathrm{~h}$, and then centrifuged at $1500 \mathrm{~g}$ for $10 \mathrm{~min}$ in an Eppendorf centrifuge (Eppendorf, San Diego, California, USA). The supernatants were collected and filtered through a $0.22 \mu \mathrm{m}$ membrane. Samples were then diluted into precooled TCA/acetone (1:9) solutions (1: $4 \mathrm{v} / \mathrm{v})$ and then stored at $-20^{\circ} \mathrm{C}$ overnight. Pellets were collected by centrifugation (Sigma Aldrich, Schnelldorf, Germany) at $17000 \mathrm{~g}$ for $30 \mathrm{~min}$, followed by washing with precooled acetone $(90 \%)$ for three times. The precipitate was airdried and then dissolved in sodium dodecyl sulfonate lysate supplementing (Beyotime, Shanghai, China) with protease inhibitor cocktail (P8340, Sigma, USA) on a homogenizer (Hai Shu Ke Sheng, Ningbo, Zhejiang, China). The crude precipitates were collected by centrifugation at $12000 \mathrm{~g}$ for $10 \mathrm{~min}$ at $4{ }^{\circ} \mathrm{C}$ (Sigma Aldrich, Schnelldorf, Germany). The supernatant was selected after sonication by centrifugation $(12,000 \mathrm{~g}$ for $15 \mathrm{~min})$ for twice. Finally, the supernatant was stored at $-80^{\circ} \mathrm{C}$ for further use. The concentration of protein was measured using BCA method [36], with BCA Protein Assay Kit (Thermo Scientific Dionex, San Jose, USA). The integrity of the extracted protein was detected by SDS-PAGE [37].

The quantified samples were then digested according to the filter aided sample preparation procedure as previously described [38]. In brief, $100 \mu \mathrm{g}$ of protein was precipitated by precooled acetone $(1: 5 \mathrm{v} / \mathrm{v})$ at $-20{ }^{\circ} \mathrm{C}$ for $1 \mathrm{~h}$, centrifuged at $16000 \mathrm{~g}$ for $10 \mathrm{~min}$ at $4{ }^{\circ} \mathrm{C}$, and vacuum freeze-dried. Protein precipitation was prepared using an iTRAQ kit (Applied Biosystems, Carlsbad, California, USA) following the manufacturer's instructions. The marked samples were then mixed, dried and then subjected to separation and identification.

\section{D-LC-MS/MS analysis}

The freeze-dried sample was dissolved in $110 \mu \mathrm{L}$ of the mobile phase A solution. Peptide separation was performed on an Agilent 1200 HPLC (Agilent Technologies, Foster City, California, USA) with the Narrow-Bore column $(2.1 \mathrm{~mm} \times$ $150 \mathrm{~mm} \times 5 \mu \mathrm{m})$, analytical guard column $(4.6 \times 12.5 \mathrm{~mm}$, 5-Micron), flow rate of $0.3 \mathrm{ml} / \mathrm{min}$, at $210 \mathrm{~nm}$ and 280 $\mathrm{nm}$ in Shanghai Luming Biotech. Co., Ltd. Reverse phase chromatographic analyses were performed using NanoRPLC Buffer A (Applied Biosystems), PepMap100C18 column $(75 \mu \mathrm{m} \times 20 \mathrm{~mm}, 3 \mu \mathrm{m}$, NanoViper; Thermo Scientific Dionex, San Jose, USA) with the mobile phase B increased from 5 to $35 \%$ in $70 \mathrm{~min}$. The Q Exactive Orbitrap mass spectrometer (Thermo Fisher Scientific, Bremen, Germany; 
nano-electrospray ionization, $1.6 \mathrm{kV}, 250^{\circ} \mathrm{C}$ ) was used for data-dependent acquisition according to the previously reported method [39].

\section{Protein identification and quantification}

The raw proteomics data in the format of raw was aligned to UniProt database (https://www.uniprot.org/) using Maxquant 1.5.1.0 (Version 1.5.1.0; Thermo Fisher Scientific). Proteins and peptides with fold discovery rate $<0.01$ were retained as for further identification of differentially expressed peptides/proteins (DEPs). The significant different proteins between groups were identified with the threshold of T-test $p$ value $\leq 0.05$ and fold change $(\mathrm{FC}) \geq 1.2$.

\section{Bioinformatics analysis}

For annotation of the DEPs, Gene Ontology (GO, http:// www.geneontology.org) and Kyoto Encyclopedia of Genes and Genomes (KEGG, http://www.genome.jp/kegg/) databases were used for the gene functions prediction. The GO classifications of molecular function, biological process and cellular component and the pathways significantly related to these DEPs were identified with the criteria of $p<0.05$.

\section{Statistical analysis}

Data were expressed as the mean \pm standard deviation. The SPSS 22.0 software was employed for the statistical analysis. One-way ANOVA test was performed to analyze the differences. Comparison of differences between groups was detected using $\mathrm{t}$-test. The $p$-value $<0.05$ was considered as significantly difference.

\section{Supplementary information}

Supplementary information accompanies this paper at https://doi.org/10. 1186/s12864-020-6531-2

Additional file 1 Figure S1. The relative abundance of the dominant bacterial phyla. $a$ and $b$, the stacked and linear figure of the relative abundance of 8 phyla during the degumming of kenaf bast, respectively.

Additional file $\mathbf{2}$ Table S1. The list of the differentially expressed proteins/peptides in the degumming of the kenaf bast.

\section{Abbreviations}

ACO: Aconitase; CFUs: Colony-forming units; DEPs: Differentially expressed proteins/peptides; FC: Fold change; GO: Gene Ontology; iTRAQ: Isobaric tag for relative and absolute quantitation; KEGG: Kyoto Encyclopedia of Genes and Genomes; OTUs: Operational taxonomic units (OTUs); rDNA: Ribosomal DNA

\section{Acknowledgements}

None.

\section{Authors' contributions}

DSW summarized the sequencing data, performed the data analysis and prepared the original manuscript. DSW and CLF attended discussion and revised MS. FXY attended data re-interpreting discussion. DSW, CLF, FXY, YQ, LZY and ZK prepared the plant material and attended the transcriptomes data analyses and discussion. DSW and PYD designed the experiments, provided research platform, performed the pathway enrichment analysis, and revised the manuscript. All authors approved the final manuscript.

\section{Funding}

National Natural Science Foundation of China (No. 31871675 and 31700438); China Agriculture Research System (No. CARS-16-E22); Chinese Agricultural Science and Technology Innovation Project (No. ASTIP-IBFC08); Natural Science Foundation of Hunan Province (No. 2019JJ40331 and 2019JJ50711). The funder had no direct role in the design and conduct of the study; collection, management, analysis and interpretation of the data; preparation, review, or approval of the manuscript; or the decision to submit the manuscript for publication.

\section{Availability of data and materials}

The original data were uploaded to SRA database (https://www.ncbi.nlm.nih. gov/sra) and the BioProject ID is PRJNA562024.

Ethics approval and consent to participate

Not applicable.

\section{Consent for publication}

Not applicable.

\section{Competing interests}

The authors declare that they have no competing interests.

Received: 2 September 2019 Accepted: 23 January 2020

Published online: 03 February 2020

\section{References}

1. Ramesh M. Kenaf (Hibiscus cannabinus L.) fibre based bio-materials: A review on processing and properties. Prog Mater Sci. 2016;78:1-92.

2. Ayadi R, Hanana M, Mzid R, Hamrouni L, Khouja M, Salhi HA. Hibiscus cannabinus L.-kenaf: a review paper. J Nat Fibers. 2017;14:466-84.

3. Ververis C, Christodoulakis N, Santas R, Santas P, Georghiou K. Effects of municipal sludge and treated waste water on biomass yield and fiber properties of kenaf (Hibiscus cannabinus L.). Ind Crop Prod. 2016;84:7-12.

4. Zaleha M, Mahzan S, Fitri M, Kamarudin K, Eliza Y, Tobi AM. Wave velocity characteristic for Kenaf natural fibre under impact damage. IOP Conf. Ser. Mater Sci Eng. 2017;165:012018.

5. Zhao D, Pan C, Ping W, Ge J. Degumming crude enzyme produced by Bacillus cereus HDYM-02 and its application in flax retting. BioResources. 2018;13:5213-24.

6. Chiliveri SR, Koti S, Linga VR. Retting and degumming of natural fibers by pectinolytic enzymes produced from Bacillus tequilensis SV11-UV37 using solid state fermentation. SpringerPlus. 2016:5:1-17. https://doi.org/10.1186/ s40064-016-2173-x

7. Duan S, Cheng L, Liu Z, Feng X, Zheng K, Peng Y. Diversity and characteristics of Kenaf Bast degumming microbial resources. J Nat Fibers. 2018:15:799-807.

8. Saha M, Rana RS, Adhikary B, Mitra S. Screening of bacterial strains for pectate lyase production and detection of optimal growth conditions for enhanced enzyme activity. J Appl Nat Sci. 2017;9:370-4.

9. Ramesh D, Ayre BG, Webber CL, D'Souza NA. Dynamic mechanical analysis, surface chemistry and morphology of alkali and enzymatic retted kenaf fibers. Text Res J. 2015:85:2059-70.

10. Cheng L, Wang Q, Feng X, Duan S, Yang Q, Zheng K, Liu Z, Liu Z, Peng Y. Screening a bacterium and its effect on the biological degumming of ramie and kenaf. Sci Agr. 2018;75:375-80.

11. Donaghy JA, Levett PN, Haylock RW. Changes in microbia populations during anaerobic flax retting. J Appl Microbiol. 2010:69:634-41.

12. Mao K, Chen H, Qi H, Qiu Z, Zhang L, Zhou J. Visual degumming process of ramie fiber using a microbia consortium RAMCD407. Cellulose. 2019;26:3513-28.

13. Shinde S. Significance of microbiological tests in technical textiles. ManMade Textiles in India. 2010:53:241-9.

14. McDevitt JP, Winkler J: Method for enzymatic treatment of wool. In: Google Patents; 2000

15. Salwan R, Sharma V, Pal M, Kasana RC, Yadav SK, Gulati A. Heterologous expression and structure-function relationship of low-temperature and alkaline active protease from Acinetobacter sp. IHB B 5011 (MN12). Int J Biol Macromol. 2018;107:567-74.

16. Kohli P, Gupta R. Application of calcium alginate immobilized and crude pectin lyase from Bacillus cereus in degumming of plant fibres. Biocatal Biotransfor. 2019;37:341-8. 
17. Salwan R, Sharma V. Proteases from Extremophilic Fungi: a tool for white biotechnology: 3rd ISNPS. France: Avignon; 2016.

18. Gundala PB, Chinthala P. Extremophilic pectinases. In: Extremophilic Enzymatic Processing of Lignocellulosic Feedstocks to Bioenergy. Springer; 2017. p. 155-80. https:/link.springer.xilesou.top/chapter/10.1007/978-3-319-54684-1_9\#citeas.

19. Polizeli M, Rizzatti A, Monti R, Terenzi H, Jorge JA, Amorim D. Xylanases from fungi: properties and industrial applications. Appl Microbiol Biot. 2005;67:577-91.

20. Tuomela M, Hatakka A, Raiskila S, Vikman M, Itävaara M. Biodegradation of radiolabelled synthetic lignin (14 C-DHP) and mechanical pulp in a compost environment. Appl Microbiol Biot. 2021;55:492-9.

21. Ribeiro A, Pochart P, Day A, Mennuni S, Bono P, Baret J-L, Spadoni J-L, Mangin I. Microbia diversity observed during hemp retting. Appl Microbiol Biot. 2015;99:4471-84.

22. Wang Q. Chen H-g, fang G, Chen A-q, Yuan P, Liu J-s. isolation of Bacillus cereus P05 and Pseudomonas sp. X12 and their application in the ramie retting. Ind Crop Prod. 2017;97:518-24.

23. Hu Q, Zhang J, Xu C, Li C, Liu S. The dynamic microbiota profile during pepper (Piper nigrum L.) peeling by solid-state fermentation. Curr Microbiol. 2017;74:739-46.

24. Zhao D, Liu P, Pan C, Du R, Ping W, Ge J. Bacterial succession and metabolite changes during flax (Linum usitatissimum L.) retting with Bacillus cereus HDYM-02. Sci Rep. 2016:6:31812.

25. Saha BC. Hemicellulose bioconversion. J ind microbiol biot. 2003;30:279-91.

26. Matte A, Forsberg CW, Gibbins AMV. Enzymes associated with metabolism of xylose and other pentoses by Prevotella (Bacteroides) ruminicola strains, Selenomonas ruminantium D, and Fibrobacter succinogenes 585. Can J Microbiol. 1992;38:370-6.

27. Van Maris AJ, Winkler AA, Kuyper M, De Laat WT, Van Dijken JP, Pronk JT. Development of efficient xylose fermentation in Saccharomyces cerevisiae: xylose isomerase as a key component: Biofuels. Springer; 2007. p. 179-204. https://link.springer.xilesou.top/chapter/10.1007/10_2007_057.

28. Moysés D, Reis V, Almeida J, Moraes L, Torres F. Xylose fermentation by Saccharomyces cerevisiae: challenges and prospects. Int J Mol Sci. 2016;17:207.

29. Solden LM, Hoyt DW, Collins WB, Plank JE, Daly RA, Hildebrand E, Beavers TJ, Wolfe R, Nicora CD, Purvine SO. New roles in hemicellulosic sugar fermentation for the uncultivated Bacteroidetes family BS11. ISME J. 2017;11:691.

30. Ludin KM, Hilti N, Schweingruber ME. Schizosaccharomyces pombe rds1, an adenine-repressible gene regulated by glucose, ammonium, phosphate, carbon dioxide and temperature. Mol Gen Genet. 1995;248:439-45.

31. Edgar RC. Search and clustering orders of magnitude faster than BLAST. Bioinformatics. 2010;26:2460-1.

32. Deepak R, Shengdar QT, Cyd K, Jennifer AF, Jeffry DS, Keith J. FLASH assembly of TALENs for high-throughput genome editing. Nat Biotechnol. 2012:30:460-5

33. Edgar RC, Haas BJ, Clemente JC, Christopher Q, Rob K. UCHIME improves sensitivity and speed of chimera detection. Bioinformatics. 2011;27:2194-200.

34. Caporaso JG, Kuczynski J, Stombaugh J, Bittinger K, Bushman FD, Costello EK, Fierer N, Peña AG, Goodrich JK, Gordon Jl, Huttley GA, Kelley ST, Knights D, Koenig JE, Ley RE, Lozupone CA, McDonald D, Muegge BD, Pirrung M, Reeder J, Sevinsky JR, Turnbaugh PJ, Walters WA, Widmann J, Yatsunenko T, Zaneveld J, Knight R. QIIME allows analysis of high-throughput community sequencing data. Bioinformatics. 2010;7:335-6.

35. Quast C, Pruesse E, Yilmaz P, Gerken J, Schweer T, Yarza P, Peplies J, Glöckner FO. The SILVA ribosomal RNA gene database project: improved data processing and web-based tools. Nucleic Acid Res. 2012;41:D590-6.

36. Smith PK, Krohn Rl, Hermanson GT, Mallia AK, Gartner FH, Provenzano MD, Fujimoto EK, Goeke NM, Olson BJ, Klenk DC. Measurement of protein using bicinchoninic acid. Anal Biochem. 1985;150:76-85.

37. Giovanni C, Maurizio B, Luca M, Laura S, Gian Marco G, Barbara C, Paola O, Luciano Z, Pier GR. Blue silver: a very sensitive colloidal Coomassie G-250 staining for proteome analysis. Electrophoresis. 2010;25:1327-33.

38. Wisniewski J, Zougman A, Nagaraj N, Mann M. Universal sample preparation method for proteome analysis. Nat Methods. 2009;6:359-62.

39. Yu H, Wang X, Xu J, Ma Y, Zhang S, Yu D, Fei D, Muhammad A. TRAQ-based quantitative proteomics analysis of molecular mechanisms associated with Bombyx mori (Lepidoptera) lanval midgut response to BmNPV in susceptible and nearisogenic strains. J Proteome. 2017;165:S1874391917302105.

\section{Publisher's Note}

Springer Nature remains neutral with regard to jurisdictional claims in published maps and institutional affiliations.

\section{Ready to submit your research? Choose BMC and benefit from}

- fast, convenient online submission

- thorough peer review by experienced researchers in your field

- rapid publication on acceptance

- support for research data, including large and complex data types

- gold Open Access which fosters wider collaboration and increased citations

- maximum visibility for your research: over $100 \mathrm{M}$ website views per year

At BMC, research is always in progress.

Learn more biomedcentral.com/submissions 